\title{
Luxury sales team ambidexterity: \\ a job demands-resources perspective
}

\author{
Matthieu Mielet \\ International University of Monaco \\ mmielet@monaco.edu
}

\begin{abstract}
Luxury sales teams must provide excellent service while still reaching their sales quotas, often under highly demanding conditions. This dual role requirement postulates flexible sales-service related behaviours, which are captured by the construct of sales-service ambidexterity. Scholars have called for research examining the individual and contextual factors that boost effective sales and service-related activities. Drawing from the job demands-resources theory, the present study proposes and tests a moderated mediation model in which: a) job demands (i.e., performance pressure, workload, emotional demands, customer treatment, manager sales versus service expectations) impair luxury sales teams' capacity to stay ambidextrous, and, indirectly, to achieve their sales and service outcomes; b) job resources (i.e., harmonious passion, emotional labor, teamness, creativity-oriented high-performance work systems, within- team knowledge sharing, leader affective presence) buffer this negative effect. This model will be tested through a time-lagged, multi-source survey on sales team members and their store managers from luxury stores. Our findings are expected to contribute to the literature sales and service behaviors in the workplace by proposing a new, stress-based perspective on the antecedents and consequences of sales- service ambidexterity. From a practical standpoint, our results are expected to provide new and relevant insights into the strategies needed to optimize the working conditions that facilitate luxury sales team dual sales-services roles in the face of stressful conditions.
\end{abstract}

Key words: Luxury salesforce, sales-service ambidexterity, JDR theory 


\section{Introduction}

The market for personal luxury goods consumption reached in 2019 a record high of $€ 281$ billion (Bain Report). High prices, prestigious images, premium product quality, scarcity, superiority, heritage and history, as well as design and aesthetics characterize luxury brands (Dubious \& Czellar, 2001; Kapferer, 2017; Keller, 2009, 2017).

One of the key moments in the journey of luxury consumptions happen during the instore experience. To create value for multifaceted luxury customers, beside products, brands strive to provide memorable experiences their clients. Salespeople are one of the keys to achieve such sales and service outcomes (Cailleux, Mignot \& Kapferer, 2009). As soon as the customers enter a store, they come into contact with salespeople. Luxury Sales Teams (LST) play an important role during this employee-customer interaction (Merck, 2019) since they stand between the brand and the customer. According to Banton (1965), a "role" is defined as a set of expectations or norms applied to the incumbent by others in the organization. Their role involves "generating sales, serving and satisfying highly demanded customers and defending their brand" (Merck, 2014, p. 29). These multiple roles inherently expose LST to job high demands. From field evidence, such teams are also exposed to other organizational, managerial (such as performance pressure, workload, manager's objectives orientation) and external (such as client mistreatment, handling of high traffic flow) conditions. These conditions represent stressful aspects of the jobs that, due to their demanding nature, might reduce LST' capacity and motivation to handle complex requirements such as their role in engaging in both sales-oriented and service-oriented behaviours. When LST are not able to handle these demands, their ambidextrous role of sales and services related activities might become weaker, and consequently the store sales and service performance might decline.

This research will extend and expand the knowledge of sale-service ambidexterity in the B2C context applied to the luxury sector by examining how LST can successfully meet their sales-services requirements in the face of demanding job conditions.

Using the framework of Job Demands-Resources, we theoretically and empirically investigate the set of negative determinants (job demands) of sales-service ambidexterity as well as the factors (job resources) that can buffer their negative effect. In addition, we 
OXFORD, UNITED KINGDOM

extend the JDR theory by offering an alternative explanation of the effects of job demands-resources on work outcomes, which considers sales-service ambidexterity, instead of work engagement (as traditionally asserted by JD-R theory), as the key mechanism responsible for transmitting such effects.

\section{Literature Review}

\subsection{Luxury Sales Teams (LST)}

Selling is a social situation in which two people come together for a specific purpose and, in doing so, influence each other (Fine et al, 1992). Salespeople must provide excellent service while still reaching their sales quotas (Agnihotri et al., 2012; Ahearne et al., 2007).

In luxury organizations, the role of LST is an essential element in the process of enhancing customer shopping experience in luxury stores (Kapferer, 1997; Scharwey \& Fassnacht, 2017). The store is where the service appears and where salespeople are in charge of representing the brand and its values (Merck, 2014).

Unlike salespeople from mass-market goods, LST operates in a world of extremes: extremely expensive products, extremely wealthy, demanding and internationally positioned customers as well as specific distribution channels (Scharwey, 2017). Therefore, the sale of a luxury product requires the addition of personalized and individual service (Kapferer \& Bastien, 2012). The advantages are evident: the service is supposed not only to increase the satisfaction and the loyalty of the customers, but also to increase the number of positive words of mouth and recommendations (Berry \& Parasuraman, 2005; Griffin, 2002).

The luxury goods industry has integrated this strategic orientation and organizations have turned to sales-service ambidexterity as a solution to increase results of both sales and service performance (Gabler, 2017). Performance is a multidimensional construct, the measurement of which varies and depends on a variety of factors that comprise it (Fitzgerald \& Moon, 1996). The sales performance is measured with the sales goal attainment. The service performance in the luxury sectors is generally measured with the mystery shopping evaluation. As such, mystery shopping can be defined as a tool to measure quality objectives (Dawes \& Sharp, 2000). 


\section{OXFORD, UNITED KINGDOM}

The Sales Service Ambidexterity (SSA) construct explores dual role capabilities and is applicable to study the role of LST. The word "ambidextrous" derives from the Latin root words ambi, meaning "both," and dexter, meaning both "right" (as opposed to "left") and "favorable." Thus, "ambidextrous" is literally "right on both sides." Ambidexterity reflects the alignment in the pursuit of seemingly incongruous goals, such as sales and service (Jasmand, Blazevic \& de Ruyter, 2012). Yu et al., (2013) defines SSA as the "twin goals of providing quality service while achieving productivity gains by meeting increased sales targets" (p. 52). High level and continuous sales-service ambidexterity positively predict store team sales and service performance for two reasons. First, employees with high work engagement are persistent and stay focused on their work tasks (Schaufeli \& Bakker, 2004), helping them fulfill their service roles efficiently and enhance their in-role performances (Christian et al., 2011) and maintain their energies and enthusiasm over long working periods (Salanova, Agut, \& Peiro, 2005).

Sales-service ambidexterity focuses on exploring sales and service as two distinctive, non-substitutable and yet interdependent activities (Rapp et al., 2017; Yu, Patterson, and de Ruyter, 2015). SSA requires skills in both elements and is measured as the product of both behaviours (Panagopulos, 2019). LST who exhibit high levels of both service and selling orientations devote time and resources toward service-focused activities as well as towards sales-focused activities. As customer-oriented salesforces, they adopt behaviours that drive customer satisfaction. They also exhibit behaviours associated with a selling orientation, striving to "stimulate demand for services or products being sold" (Huang, 2008, p. 462). Sales growth can be achieved by selling higher volumes to existing clients or by converting new customers. For their part, service behaviours involve a 'conversation with customers' where salespeople put a greater effort to understand and meet the customer needs while continuing to develop the relational dimension of the exchange.

Accumulating empirical evidence suggests that the ability to deploy both capabilities simultaneously result in increased levels of performance (Lubatkin et al. 2006; Yu, Patterson, and de Ruyter, 2013). Ambidexterity has a positive impact on the customer experience and, consequently, on the performance of the organizational frontline. Therefore, companies have a strong interest in cultivating sales-service ambidexterity as a solution for frontline performance (Evans, Arnold, \& Grant, 1999; Jasmand, Blazevic, \& de Ruyter, 2012). 


\section{OXFORD, UNITED KINGDOM}

They are two characteristics that facilitate the interaction and combination of sales and service activities: the organizational environment, such as specific processes and systems, and aspects related to individual employees (de Ruyter, 2019). Rapp (2016) invites to research on the antecedents and determinants of SSA.

\subsection{A Job Demands-Resources perspective on LST}

JD-R theory can be applied to study all work environments and can be tailored to the specific occupation under consideration. The Job Demands-Resources (JD-R) perspective sheds light on an increasingly complex frontline role (Jones et al., 2005). We propose to use this model to understand the conditions of LST role execution and the underlying psychological dynamics in terms of stress and motivational processes. With JD-R theory, we can understand, explain, and make predictions about the nature of the interactive between of job demands and resources on LST store outcome (store sales and service performance) and the underlying mechanisms.

According to the JD-R model (Demerouti et al., 2001), the characteristics of work environment can be classified in two general groups, job demands and job resources, which include different specific demands and resources, depending on the context under study. These two categories of work characteristics evoke two relatively independent psychological processes. According to the health impairment process, high job demands, which require sustained effort, may exhaust employees' resources and lead to energy depletion and health problems (Caplan, Cobb, French, Harrison, \& Pinneau, 1975). This stressor, as an external factor, features a negative impact on work engagement.

On the other hand, according to the motivational process, the availability of job resources leads to organizational commitment and work engagement (Schaufeli \& Bakker, 2004). Job resources, due to their (intrinsic and extrinsic) motivational potential, foster employees to meet their goals. Bakker (2006) suggest that the job resources lie at the levels of the organization (e.g. pay, career opportunities, job security), of the interpersonal and social relations (e.g. supervisor and co-worker support, team climate), of the organization of work (e.g. role clarity, participation in decision making), and of the task (e.g. skill variety, task identity, task significance, autonomy, performance feedback). Resources also incorporate individual factors, recognized as the aspects of self that are generally linked to resilience and refer to individuals' sense of their ability 
to successfully control and influence their environment (Hobfoll, Johnson, Ennis, \& Jackson, 2003).

Work engagement is often analysed as a mediating variable between the JD-R model and outcomes (Schaufeli, 2015). Work engagement is defined as " [ . . . ] a positive, fulfilling, work-related state of mind that is characterized by vigor, dedication, and absorption" (Schaufeli, Salanova, González-Romá \& Bakker, 2002, p. 74). In the configuration of LST dual sales service roles, work engagement relates to LST continuous effort to pursue and demonstrate sales-service ambidexterity behaviours. Drawing on this theory, we thus focus on SSA, rather than on the general state of work engagement, as a more motivational factors that is more tailored to the sales context and that, accordingly, is more likely to account for the interactive effects of job demands and resources of store sales and service performance.

\section{Research objectives \& hypothesis}

To effectively understand LST sales-service ambidexterity and brings a new perspective at its antecedents and consequences, a conceptual framework is needed that encompasses job demands, job resources, sales-service ambidexterity and store team performance at sales and service levels. SSA is positioned as the role of mediator in this JDR framework. We advance a multidimensional model that posit sales-service ambidexterity as a mediator of job demands over store sales and service performance and job resources as a moderator of job demands over store sales and service performance.

\section{Hypothesis 1}

SSA will mediate a negative relationship of job demands with team's sales performance and service performance.

\section{Hypothesis 2}

Job resources will moderate the negative relationships of job demands with team's sales performance and service performance, such that such that this relationship will be weaker when job resources are higher. 
OXFORD, UNITED KINGDOM

\section{Research Method}

Empirical research is approached in two stages with qualitative and quantitative methods. The first stage has been completed allowing to identify job demands-resources variables relevant to luxury sales team's context. Quantitative research is currently undergoing to test the conceptual framework.

\subsection{Variables of the conceptual framework}

Job demands and job resources are not measured by themselves but by other subvariables that represent them. Nine field interviews were conducted with sales team randomly selected from luxury beauty brand stores in Paris. Interviews were conducted in French. The determination of the sample size followed the principle of theoretical saturation (Glaser, 1978) when the information of the respondents became repetitive and the analytical categories rich of information (Quinn-Patton, 2015). We analysed the data material individually and according to the principles of inductive-deductive data analysis (Spiggle, 1994; Srnka \& Koeszegi, 2007). Selective coding and constant comparison (Charmaz, 2006; Glaser, 1978) identified 5 job demands and 6 job resources variables to be included in the conceptual framework. The job demands variables are (1) performance pressure (set of interrelated factors that increases a team's accountability for high-quality performance as a key force influencing team knowledge-use processes and therefore team effectiveness. Mitchell et al., 2019); (2) workload (situation where employees filled with a pile of tasks and the inability to complete the tasks within the given time leading to high job stress and job strain, which in turn result in negative work outcomes. Zahrah et al., 2019); (3) emotional demands (aspects of job that require sustained emotional effort due to interactional contacts with clients and co-workers. Azharudeen \& Arulrajah, 2018); (4) customer treatment (low-quality interpersonal treatment that employees receive from their customers invoking negative feelings and compromising service employees' short-term and long-term emotional well-being. Song, Yifan, et al., 2018); (5) manager sales versus service expectations (role of leaders' normative expectations as perceived by the luxury sales team in driving employee performance. Binyamin, 2018). The job resources variables are (1) harmonious passion (autonomous motivation by which individuals freely and volitionally view work as important to their identities because of characteristics of the work itself. Amarnani et al., 2019); (2) emotional labor 


\section{OXFORD, UNITED KINGDOM}

(regulation of one's emotion to comply with occupational or organizational norms to create a publicly observable facial and bodily display. Zhao \& Freene, 2018 ); (3) teamness (ability of individuals to collaborate and work effectively as a team through close relationships among team members, their strong commitment to the team's success, and a perceptible unity of team members. Stawnicza, 2015); (4) creativity-oriented highperformance work systems (systems of human ressources practices designed to enhance employees' competencies, motivation, and opportunity for creative performance. Martinaityte et al., 2015); (5) within-team knowledge sharing (process in which an individual shares its relevant knowledge, ideas, suggestions, and skills with other team members. Men et al., 2019); (6) leader affective presence (positive social exchanges between leaders and their employees that enhance employees' positive motivation and performance. Jiang et al., 2019).

\subsection{Testing of the conceptual framework}

The conceptual framework will be tested through a time-lagged, multi-source survey on sales team members and their store managers from beauty brands luxury stores located in Europe in the markets of France, Italy, Germany, Switzerland and the United Kingdom. These brands belong to the luxury division of a leading French beauty group. Two questionnaires have been designed and will be administered to salespersons and to store managers.

Before data collection, each questionnaire will be pre-tested with their respective groups to check the clarity and relevance of each scale and item in the luxury selling context. Based on feedback from respondents, questions will be refined with appropriate guidance for better fit within luxury sales settings. Lastly, two academics will review the items of the survey providing support for face validity in luxury sales contexts.

In total, 90 store manager surveys and 180-240 sales team members surveys are expected to be collected as preliminary data. Store managers will be asked to report their team's sales goal attainment, team service performance evaluation of the past month along with the team's service goal attainment indicated by the mystery shopping score of the past wave. LST will be asked to evaluate 11 scales regarding job demands, job resources and 
SSA. A Code number will be assigned to each store then used to match the salespersons and the store manager responses while enabling accuracy and anonymity.

All measures are adapted from previously developed multi-item scales. For all scales, participants respond on a 5-point Likert-type scale with responses ranging from 1 (strongly disagree) to 5 (strongly agree) to indicate agreement with statements reflected in the items.

\subsection{Control Variables}

The following control variables will be included in the questionnaire: age, gender, nationality, education level, organizational tenure. We assumed that depending on a person's age, job level, education level, and organizational tenure, people would have different capacity levels to engage in sales-service ambidexterity. Because of luxury context effect, we also included a scale of perceived luxuriousness of the brand (Parguel et al., 2016) to control for its effect on sales-service processes and outcomes.

\section{Conclusion}

This research will contribute to the literature on luxury sales forces management by empirically testing the job demands that prevent LST from staying ambidextrous as well as the job resources help LST manage these job demands and, therefore, allow role ambidexterity. It will shed new light on the JDR theory application.

Once completed, findings from empirical research will provide insights and implications for practitioners on how to manage luxury store teams' sales-service behaviours to drive higher sales-service store performance. These results will allow identifying strategies for luxury retail managers and stores managers to reduce and control the effects of the job demands, and encourage the development of certain job resources that can improve LSTs' ambidexterity and the related sales-service outcomes. 
OXFORD, UNITED KINGDOM

\section{References}

Agnihotri, R., Gabler, C. B., Itani, O. S., Jaramillo, F., \& Krush, M. T. (2017). Salesperson ambidexterity and customer satisfaction: Examining the role of customer demandingness, adaptive selling, and role conflict. Journal of Personal Selling \& Sales Management, 37(1), 27-41.

Bakker, A. B., \& Albrecht, S. (2018). Work engagement: current trends. Career Development International, 23(1), 4-11.

Bakker, A. B., \& Demerouti, E. (2007). The job demands-resources model: State of the art. Journal of managerial psychology, 22(3), 309-328.

de Ruyter, K., Keeling, D. I., \& Yu, T. (2019). Service-Sales Ambidexterity: Evidence, Practice, and Opportunities for Future Research. Journal of Service Research, 1094670519878880.

Gabler, C. B., Ogilvie, J. L., Rapp, A., \& Bachrach, D. G. (2017). Is there a dark side of ambidexterity? Implications of dueling sales and service orientations. Journal of Service Research, 20(4), 379-392.

Hughes, D. E., \& Ogilvie, J. L. (2019). When Sales Becomes Service: The Evolution of the Professional Selling Role and an Organic Model of Frontline Ambidexterity. Journal of Service Research, 1094670519878882.

Jasmand, C., Blazevic, V., \& De Ruyter, K. (2012). Generating sales while providing service: A study of customer service representatives' ambidextrous behavior. Journal of Marketing, 76(1), 20-37.

Merk, M. (2014). Luxury sales force management: Strategies for winning over your brand ambassadors. Springer.

Merk, M., \& Michel, G. (2019). The dark side of salesperson brand identification in the luxury sector: When brand orientation generates management issues and negative customer perception. Journal of Business Research. 
OXFORD, UNITED KINGDOM

Michel, G., Merk, M., \& Eroglu, S. (2015). Salesperson-brand relationship: main dimensions and impact within the context of private brand retailing. Journal of Personal Selling \& Sales Management, 35(4), 314-333.

Mullins, R., Agnihotri, R., \& Hall, Z. (2019). The Ambidextrous Sales Force: Aligning Salesperson Polychronicity and Selling Contexts for Sales-Service Behaviors and Customer Value. Journal of Service Research, 1094670519883344.

Panagopoulos, N. G., Rapp, A., \& Pimentel, M. A. (2019). Firm Actions to Develop an Ambidextrous Sales Force. Journal of Service Research, 1094670519883348. ISO 690

Patterson, P., Yu, T., \& Kimpakorn, N. (2014). Killing two birds with one stone: Crossselling during service delivery. Journal of Business Research, 67(9), 1944-1952.

Rapp, A., Baker, T., Hartmann, N. N., \& Ahearne, M. (2019). The Intersection of Service and Sales: The Increased Importance of Ambidexterity. Journal of Service Research, 1094670519892333.

Rapp, A. A., Bachrach, D. G., Flaherty, K. E., Hughes, D. E., Sharma, A., \& Voorhees, C. M. (2017). The role of the sales-service interface and ambidexterity in the evolving organization: A multilevel research agenda. Journal of Service Research, 20(1), 59-75.

Scharwey, A. C., \& Fassnacht, M. (2017). Luxury-Specific Dimensions of CustomerSalesperson Relationships. In Luxusmarkenmanagement (pp. 421-436). Springer Gabler, Wiesbaden.

Schaufeli, W. B. (2017). Applying the job demands-resources model. Organizational Dynamics, 2(46), 120-132.

Sok, K. M., Sok, P., \& De Luca, L. M. (2016). The effect of 'can do'and 'reason to'motivations on service-sales ambidexterity. Industrial Marketing Management, 55, 144-155.

Yu, T., Patterson, P. G., \& de Ruyter, K. (2013). Achieving service-sales ambidexterity. Journal of Service Research, 16(1), 52-66. 
OXFORD, UNITED KINGDOM

Yu, T., Patterson, P., \& de Ruyter, K. (2015). Converting service encounters into crossselling opportunities. European Journal of Marketing. 